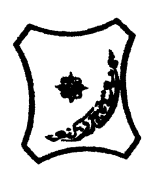

Bayero Journal of Pure and Applied Sciences, 14(1):214 - 220

Received: June, 2021

Accepted: May, 2021

ISSN $2006-6996$

\title{
ANTIBACTERIAL ACTIVITY AND TOXICOLOGICAL EVALUATION OF Anogeissusleiocarpus AND Psidium guajava ON Escherichia coli and Staphylococcus aureus
}

\author{
Yabo, S. A ${ }^{1}$., Manga, S. B ${ }^{2}$, Baki, A. $\mathbf{S}^{2}$., Atata, R. $\mathbf{F}^{3}$., Gambo, S. $^{4}$ and Tahir, $\mathbf{H}^{5}$. \\ 1. College of Nursing Sciences, Sokoto. \\ 2. Department of Microbiology, Usmanu Danfodiyo University, Sokoto. \\ 3. Department of Pharmaceutical Microbiology, Usmanu Danfodiyo University, Sokoto. \\ 4. Department of Microbiology, Federal University Gusau. \\ 5. Department of Medical Laboratory Technology, Abubakar Tatari Ali Polytechnic Bauchi.
}

ABSTRACT

The study was carried out to determine the antibacterial activities and toxicological evaluation of Anogeissusleiocarpus and Psidiumguajava on Escherichia coli and Staphylococcus aureus isolated from clinical samples. The plants leaves were extracted using Hexane, Methanol, Ethanol and Water. Various concentrations (50, 25, 12.5 and $6.25 \mathrm{mg} / \mathrm{ml})$ of the crude extract of the plants were prepared and their antibacterial activity against Staphylococcus aureus and E. coli was determined using Agar well (Diffusion) method. Toxicity of the plants was evaluated, acute toxicity test, kidney and liver function tests. The result revealed that at $50 \mathrm{mg} / \mathrm{ml}$ concentration, the leaf extract of Psidiumguajava was active against Staphylococcus aureus and E. coliexhibiting the highest zones of inhibition of $19 \mathrm{~mm}$ and $9 \mathrm{~mm}$ respectively. Whereas The leaf extract of Anogeissusleiocarpus only inhibited the growth of Staphylococcus aureus recording highest zone of inhibition of $15 \mathrm{~mm}$ at a concentration of $50 \mathrm{mg} / \mathrm{ml}$. The plant extracts were found to be non-toxic as the $L D_{50}$ was above $5000 \mathrm{mg} / \mathrm{kg}$ and the biochemical parameters evaluated for both liver and kidney function tests revealed values that are within normal range. Hence the study established that consumption of the leaves of $P$. guajava for medicinal purpose can be said to be innocuous, as such the plant could be regarded as a potential candidate in the search of potent and harmless plants of therapeutic value.

Keywords: Anogeissusleiocarpus, Escherichia coli, Psidiumguajava and Staphylococcus aureus

\section{INTRODUCTION}

In recent years there is increasing incidence of multiple antibiotic resistances in human pathogenic microorganisms, largely due to the indiscriminate use of commercial antimicrobial drugs commonly employed in the treatment of infectious diseases (Parekh and Chanda, 2007). The implication is that many antibiotics have failed in the treatment of some infectious diseases. This has forced scientist to search for new antimicrobial substances from various sources like medicinal plants. Search for new antibacterial agents is on the increase by the screening of many plant families (Parekh and Chanda, 2007).

Psidium guajava called guava is an evergreen small tree. The leaves are 2-6inches long and 12 inches wide, aromatic when crushed, and appeared dull-green with stiff but coriaceous with pronounced veins (Garode and Waghode, 2014). Psidium guajava (guava) is commonly known for its food and nutritional values, the medicinal properties of the leaves are also well known in traditional system of medicine (Garode and Waghode, 2014).

Anogeissus leiocarpus is a deciduous tree growing up to $30 \mathrm{~m}$ in height, typically $15-18 \mathrm{~m}$ with light green foliage, Leaves are alternate to sub-opposite, elliptic to ovate-lanceolate in shape, and $2-8 \mathrm{~cm}$ long and $1.5-3.5 \mathrm{~cm}$ across (Klaus et al., 2004). The stem are finely pubescent, the bark is grey to beige in colour, becoming blackish with age, and fibrous with thin scales. Anogeissus leiocarpus contains about 40 wind dispersed seeds of $10 \mathrm{~g}$ each (Klaus et al., 2004).

Resistance to antimicrobial agents is a major global public health problem. Synthetic drugs are expensive, not always available; the good ones are not available and affordable especially in rural areas and are also associated with adverse side effect. 
BAJOPAS Volume 14 Number 1,June, 2021

Increase development of resistance to current antibiotics has strengthened scientific research for discovery of new drugs that are potent, cheap, readily available, and affordable and with no or less side effects. Anogeissus leiocarpus and Psidium guajava ranked top in the list of medicinal plants in Hausa -Fulani land known for their therapeutic benefits. However, not much research has been done to scientifically evaluate and reconcile the antibacterial potentials of these plants against the traditional claims. This study was aimed at evaluating antibacterial activities and toxicological studies of Anogeissus leiocarpus and Psidium guajava againstEscherichia coli and Staphylococcus aureus.

\section{MATERIALS AND METHODS}

Collection, Identification and Extraction of plant materials

Fresh samples (leaves) of Anogeissus leiocarpus and Psidium guajava plant were collected from the Usmanu Danfodiyo University, Sokoto Biological Garden. Voucher specimens were kept at the herbarium of Botany unit in the department of Biological Sciences. The leaves of the plants Anogeissus leiocarpus and Psidium guajava were rinsed with clean water and air dried under shed at room temperature for two weeks. Each of the air dried samples were pounded manually with a clean pestle and mortar, the powdered leaves were sieved, weighed and stored in a clean sterile containers ready for use according to the methods of Oyeleke and Manga (2008).

\section{Extraction of the plants materials}

The soxhlet method of extraction was employed in extracting the plants materials using Hexane, Methanol, Ethanol, and Water. A weight of $500 \mathrm{~g}$ of each of the powdered plants samples were placed in the upper chamber in a thimble, and $500 \mathrm{ml}$ of the solvent (hexane, methanol, ethanol, and water each) in the bottom flask. The pulverized leaves of both $A$. leiocarpus and $P$. guajava were defatted exhaustively with the above solvents by successive soxhlet extraction according to the method of National Institute for Pharmaceutical Research Development protocol (2004). The extracted solutions were concentrated in a rotary evaporator according to the method of Oyeleke and Manga (2008). The extracts were weighed and kept in well labelled sterile sample bottles for further analysis.

\section{Preparation of Concentrations of the} crude Plants Extracts

A test stock concentration of $500 \mathrm{mg} / \mathrm{ml}$ for methanol, ethanol, and water extract of $A$. leiocarpus and $P$. guajava (leaves) were prepared by dissolving $1 \mathrm{~g}$ of each extract in
$2 \mathrm{mls}$ of sterile distilled water in separate test tubes. Non-polar hexane extract was first homogenised in $0.1 \mathrm{ml}$ dimethyl sulfoxide (DMSO) and then added to $1.9 \mathrm{ml}$ of distilled water. $0.1 \mathrm{ml}$ of the stock concentration equivalent to $50 \mathrm{mg}$ was used to prepare different concentrations of the plants extract by doubling dilution $(50,25,12.5$ and $6.25 \mathrm{mg} / \mathrm{ml}$ ) (Oyeleke and Manga, 2008). The different concentrations of the crude plant extracts were assayed for their antibacterial activity against the test bacteria. The positive control drugs used was Tetracycline $(0.5 \mathrm{mg} / \mathrm{ml})$.

\section{Test Bacteria}

The isolates (Staphylococcus aureus and Escherichia Coll) were isolated from urine and wound samples following standard procedures for sample collection, isolation and identification (Gram staining, biochemical test and serological test) (Koneman et al, 2005).

\section{Determination of Antibacterial Activity} of the crude extract

Bacteria identified and characterized by standard biochemical methods (Staphylococcus aureus and Escherichia coli) were tested for their sensitivity to the crude plant extracts using the agar well diffusion method described by Hugo and Russel (1992).

The suspension of the bacterial inoculums that matched McFarland scale 0.5 , were spread on the surface of a Muller Hinton agar plate with sterile bent glass rod. A standard cork borer of $6 \mathrm{~mm}$ in diameter was used to cut 6 wells at the centre of each inoculated plate and the agar removed from the well. A $0.1 \mathrm{ml}$ of each extracts (at concentrations of $50,25,12.5$ and $6.25 \mathrm{mg} / \mathrm{ml}$ ) were introduced into the wells. A positive control $(0.5 \mathrm{ml} / \mathrm{mg})$ of Tetracycline was placed in one of the wells. Sterilized distilled water was used as negative control. The plates were incubated at $37^{\circ} \mathrm{C}$ for $24 \mathrm{hrs}$, and observed for the zone of inhibition of the growth. The zones were measured with a transparent ruler and the result recorded in millimetres. The screening was done in triplicates.

\section{Toxicity studies}

Evaluation of the toxicity of the plant extract with the highest antibacterial activity against the test bacteria was carried out using acute toxicity studies. Adult albino rats weighing $190-200 \mathrm{~g}$ of the same age group born on the same date were used after being certified healthy by a veterinary doctor. The animals were kept at animal house in a cage at Usmanu Danfodiyo University Sokoto Biological Garden where they were maintained under veterinary supervision and were fed well with standard growers "vital feed" and have access to water for 3days to 
BAJOPAS Volume 14 Number 1,June, 2021

acclimatize before commencement of the The animals were housed and cared for in accordance with good laboratory practice (GLP) regulation of WHO (2008).

The acute toxicity test was carried out according to the method described by Aboudoulatif et al. (2010) with slight modification using thirty (30) albino rats. The limit test dose of $2000 \mathrm{mg} / \mathrm{kg}$ and $5000 \mathrm{mg} / \mathrm{kg}$ body weight as stipulated in the Organization for Economic Corporation Development (OECD) guidelines were used. The rats were grouped into three (3) groups, containing ten (10) rats each, and then $2000 \mathrm{mg} / \mathrm{kg}$ and $5000 \mathrm{mg} / \mathrm{kg}$ body weight of methanolic leave extract of $P$. guajava were administered orally with cannula attached to a graduated syringe to the first two groups, while the last group received only distilled water and served as control. The animals were observed individually for the first eight (8) hours for acute toxicity signs, behavioural changes, and at least once daily for 14 days, the first day was taken as D0 whereas the day of sacrifice was designated as D14.

The rats were sacrificed after 14days and some biochemical parameters for liver and kidney function were estimated and recorded. The function of liver was evaluated using key parameters such as alkaline phosphate (ALP), aspartate transaminase (AST), alanine transaminase (ALT), albumin, total bilirubin and divided bilirubin. The kidney function was evaluated using parameters such as urea, creatinine, sodium, potassium and chlorine ions. experiment.

On day 14 after administration, all the albino rats were sacrificed (by slaughtering). Blood samples were immediately collected from each sacrificed rat into well labelled clean plastic test tubes and allowed to stand to ensure complete clotting. The clotted blood samples were centrifuged at $3000 \mathrm{rpm}$ for $10 \mathrm{mins}$; clear serum samples were aspirated and stored frozen. The effect of the crude extracts on the biochemical parameters were determined using the procedures and reagents of agappe diagnostics Ltd.(2013). At Usmanu Danfodiyo University Teaching Hospital Sokoto (chemical pathology lab).

\section{RESULTS}

The results of the study revealed that the Anogeissus leiocarpus leaves had antibacterial activity only against Staphylococcus aureus while Psidium guajava was active against both Staphylococcus aureus and E. coli. Table 1 shows thatat a concentration of $50 \mathrm{mg} / \mathrm{ml}$, methanol leave crude extract and aqueous leave crude extract inhibited the growth of Staphylococcus aureus producing a zone of inhibition of $15 \mathrm{~mm}$ and $9 \mathrm{~mm}$ respectively. At $25 \mathrm{mg} / \mathrm{ml}$ concentration also the methanol and aqueous extract inhibited the growth of Staphylococcus aureus producing an inhibition zone of $13 \mathrm{~mm}$ and $7 \mathrm{~mm}$ respectively (Table 1 ). However, at $12.5 \mathrm{mg} / \mathrm{ml}$ concentration only the methanol leaves crude extract inhibited the growth of Staphylococcus aureus producing $11 \mathrm{~mm}$ inhibition zone (Table 1).

Table 1: Antibacterial activity of the crude extracts of Anogeissus leiocarpus leaves

\begin{tabular}{|c|c|c|c|c|c|c|c|c|}
\hline \multirow{3}{*}{ Conc. $(\mathrm{mg} / \mathrm{ml})$} & \multicolumn{8}{|c|}{ Mean of the zone of inhibition $(\mathrm{mm}) /$ Conc. of extracts $(\mathrm{mg} / \mathrm{ml})$} \\
\hline & \multirow{2}{*}{\multicolumn{2}{|c|}{$\begin{array}{c}\text { Hexane } \\
\text { S. aureus E. coli }\end{array}$}} & \multicolumn{2}{|c|}{ Methanol } & \multicolumn{2}{|c|}{ Ethanol } & \multicolumn{2}{|l|}{ Aqueous } \\
\hline & & & S. aureus & E. coli & S. aureus & E. coli & S. aureus & E. coli \\
\hline 6.25 & - & - & - & - & - & - & - & - \\
\hline 12.5 & - & - & 11 & - & - & - & - & - \\
\hline 25.0 & - & - & 13 & - & - & - & 7.0 & - \\
\hline 50.0 & - & - & 15 & - & - & - & 9.0 & - \\
\hline (Tetracycline) & 28 & 22 & 26 & 22 & 28 & 18 & 30 & 28 \\
\hline Distilled water & - & - & - & - & - & - & - & - \\
\hline
\end{tabular}

Key: - = No inhibition;

Table 2 shows that the highest antibacterial activity of Psidium guajava leaves crude extract against Staphylococcus aureus and E. coli was produced by the methanol extract at the concentration of $50 \mathrm{mg} / \mathrm{ml}$ which produces a zone of inhibition of $19 \mathrm{~mm}$ and $9 \mathrm{~mm}$ respectively. Similarly, at $50 \mathrm{mg} / \mathrm{ml}$ concentration, the ethanol leaves crude extract inhibited the growth of Staphylococcus aureus producing an inhibition zone of $12 \mathrm{~mm}$. The lowest zone of inhibition of $6 \mathrm{~mm}$ was produced by the ethanol extract at the concentration of $12.5 \mathrm{mg} / \mathrm{ml}$ (Table 2). 
BAJOPAS Volume 14 Number 1,June, 2021

Table 2: Antibacterial Activity of the Crude Extracts of Psidium guajava leaves

\begin{tabular}{|c|c|c|c|c|c|c|c|c|}
\hline \multirow{3}{*}{$\begin{array}{c}\text { Conc. } \\
(\mathrm{mg} / \mathrm{ml})\end{array}$} & \multicolumn{8}{|c|}{ Mean of the zone of inhibition $(\mathrm{mm}) /$ Conc. of extracts $(\mathrm{mg} / \mathrm{ml})$} \\
\hline & Hexa & ne & & Methan & & Ethanol & & Aqueous \\
\hline & $\begin{array}{l}\text { S. aureus } \\
\text { E. coli }\end{array}$ & E. coli & & S. aureus & E. coli & S. aureus & E. coli & S. aureus \\
\hline 6.25 & - & - & - & - & - & - & - & - \\
\hline 12.5 & - & - & 10 & - & 6.0 & - & - & - \\
\hline 25.0 & - & - & 15 & 6.0 & 10 & - & - & - \\
\hline 50.0 & - & - & 19 & 9.0 & 12 & - & - & - \\
\hline (Tetracycline) & 30 & 28 & 28 & 28 & 28 & 28 & 28 & 28 \\
\hline Distilled water & - & - & - & - & - & - & - & - \\
\hline
\end{tabular}

Key: - = No inhibition;

The results of the general appearance and behavioural observation for the treated animals and control group are presented in Table 3. The results indicated that there were no any physical or behavioural changes between the treated and control groups of the albino rats following the administration of the crude methanolic leaves extract of $P$. guajava at 2000 and $5000 \mathrm{mg} / \mathrm{kgbw}$ doses.

Table 3: Behavioural observations of the control and treated rats

\begin{tabular}{lllll}
\hline Observation & Control group & & Treated group & \\
\hline Time & 8hrs & 14days & 8 hrs & 14days \\
Activity & Active & Active & Active & Active \\
Breathing & Normal & Normal & Normal & Normal \\
Convulsions & Absent & Absent & Absent & Absent \\
Ears and eyes & Normal & Normal & Normal & Normal \\
Injury & Absent & Absent & Absent & Absent \\
Skin changes & Absent & Absent & Absent & Absent \\
Salivation & Absent & Absent & Absent & Absent \\
Mortality & Absent & Absent & Absent & Absent \\
\hline
\end{tabular}

Table 4a contain the result of acute toxicity test, it show that no death was recorded following the oral administration of the methanol extract of Psidiumguajava at dose limits of $2000 \mathrm{mg} / \mathrm{kgbw}$ and $5000 \mathrm{mg} / \mathrm{kgbw}$.
Table $4 \mathrm{~b}$ contain the result of the parameters use in determining the $\mathrm{LD}_{50}$. As no death was recorded among all the test rats it indicated that the $\mathrm{LD}_{50}$ for methanol extract of Psidiumguajava is above $5000 \mathrm{mg} / \mathrm{kgbw}$.

Table 4a: Toxicity test of Psidium guajava in Rats.

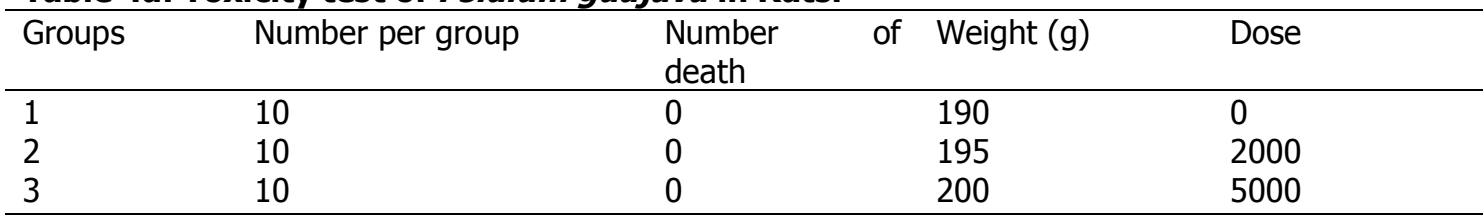

Table 4b: Determination of $\mathrm{LD}_{50}$ of methanol leave extract of Psidium guajava in rats

\begin{tabular}{lllll}
\hline Dose & Number of death & Mean death & Dose difference & $\begin{array}{l}\text { Mean } \\
* \text { dose } \\
\text { difference }\end{array}$ \\
\hline $0.000 \mathrm{mg} / \mathrm{kg}$ & 0 & 0 & 0 & 0 \\
$2000 \mathrm{mg} / \mathrm{kg}$ & 0 & 0 & $2000 \mathrm{mg}$ & 0 \\
$5000 \mathrm{mg} / \mathrm{kg}$ & 0 & 0 & $3000 \mathrm{mg}$ & 0 \\
\hline
\end{tabular}

The results of the liver and kidney function test of the treated and control group of the albino rats were presented in Table 5 and 6 respectively. Table 4 revealed that with the exception of ALP which was significantly higher, the values of all the biochemical parameters were similar for the control and treated groups. Table 5 revealed that, for the kidney function test the values of all the biochemical parameters were similar for the control and treated groups. 
Table 5: Effect of crude methanolic leaves extract of $P$. guajava on liver function

\begin{tabular}{lllll}
\hline Parameters & $\begin{array}{l}\text { Control group } \\
\mathbf{0 . 0 0 0} \mathbf{m g} / \mathbf{k g b w}\end{array}$ & $\begin{array}{l}\text { Group treated } \\
\mathbf{2 0 0 0} \mathbf{m g} / \mathbf{k g b w}\end{array}$ & $\begin{array}{l}\text { Group treated } \\
\mathbf{5 0 0 0} \mathbf{m g} / \mathbf{k g b w}\end{array}$ & with \\
\hline AST & $70.6 \pm 2.79$ & $68.1 \pm 5.23$ & $64.6 \pm 15.2$ \\
ALP & $273 \pm 1.30$ & $836 \pm 5.03$ & $923 \pm 9.91$ \\
ALT & $110 \pm 0.26$ & $139 \pm 11.2$ & $139 \pm 9.50$ \\
Albumin & $2.80 \pm 2.10$ & $2.67 \pm 0.24$ & $2.88 \pm 0.12$ \\
Total bilirubin & $0.73 \pm 1.55$ & $0.86 \pm 0.12$ & $0.80 \pm 0.10$ \\
Divided bilirubin & $0.13 \pm 1.24$ & $0.08 \pm 1.27$ & $0.06 \pm 1.45$ \\
\hline
\end{tabular}

Key: $\mathrm{Mg} / \mathrm{kgbw}=$ Milligram per Kilogram body weight; AST = Aspartate transaminase, ALP = Alkaline phosphate, $A L T=$ Alanine transaminase. Note: Values are mean \pm S.E.M for $n=10$

Table 6: Effect of the methanolic leaf extract of $P$. guajava on the kidney function

\begin{tabular}{|c|c|c|c|}
\hline Parameters & $\begin{array}{l}\text { Control group } \\
0.000 \mathrm{mg} / \mathrm{kgbw}\end{array}$ & $\begin{array}{l}\text { Group treated with } \\
2000 \mathrm{mg} / \mathrm{kgbw}\end{array}$ & $\begin{array}{l}\text { Group treated with } \\
5000 \mathrm{mg} / \mathrm{kgbw}\end{array}$ \\
\hline Urea & $6.79 \pm 0.44$ & $6.96 \pm 1.16$ & $7.0 \pm 0.73$ \\
\hline Creatinine & $0.73 \pm 0.17$ & $0.72 \pm 0 . .22$ & $0.78 \pm 0.17$ \\
\hline Sodium ion $\left(\mathrm{Na}^{+}\right)$ & $135.5 \pm 0.84$ & $134.2 \pm 0.78$ & $135.8 \pm 1.47$ \\
\hline Potassium ion $\left(\mathrm{K}^{+}\right)$ & $4.51 \pm 0.12$ & $4.41 \pm 0.26$ & $4.44 \pm 0.06$ \\
\hline Chlorine ion $\left(\mathrm{CL}^{-}\right)$ & $96.3 \pm 0.94$ & $95.9 \pm 1.91$ & $97.3 \pm 1.25$ \\
\hline
\end{tabular}

Key: $\mathrm{Mg} / \mathrm{kgbw}=$ Milligram per Kilogram body weight. Note: Values are mean \pm S.E.M for $\mathrm{n}=10$

\section{DISCUSSION}

The findings of the study indicated that the crude extracts of Anogeissus leiocarpus and Psidium guajava leaves possess an antibacterial activity against the test organisms. The study showed that the antibacterial activities of both the two plants decreases with decrease in the concentration of the extracts producing lower inhibition zones against the test isolates at the lowest concentration of $6.25 \mathrm{mg} / \mathrm{ml}$ and higher inhibition zones at the highest concentration of $50 \mathrm{mg} / \mathrm{ml}$.- This implies that the higher the concentration of the extract, the higher the antibacterial activity, thus, indicating a concentration dependent activity of the test extract. This is in agreement with the observation of the concentration dependent nature of antibiotics in which the rate of bacterial eradication increases with increase in concentration of the drug (El-Mahmood et al., 2010).

The study illustrated that the methanol extract of Anogeissus leiocarpus have higher antibacterial activity than the other solvents. Similar findings have reported methanol to be more efficient in extracting substances from medicinal plants. This may have been due to the better solubility of the bioactive agents as polarity increased (El-Mahmood et al., 2010). Hexane and ethanol extract did not inhibit the growth of the test bacteria.

The study reports that methanol and ethanol extract of Psidium guajava exhibited antibacterial activity against both the two test bacteria (E.coli and $S$. aureus). This is line with the work of Abdelrahim et al (2002) who reported that Guava leaf extract inhibited the growth of $S$. aureus in a study carried out using disc diffusion method. It also support the findings of Rabe and Van Staden (1997) which showed that greater overall antimicrobial activity was seen with methanol extract than with other extracts. However, the finding of this research is in contrast to the findings reported by Jajari et al. (1999) who obtained better results from aqueous extracts than from methanol extract. The difference in the extract performance suggests that there are multiple and different antimicrobial agents present in each type of extract acting in different ways on different bacterial strains.

Acute Toxicity study was conducted at doses of $2000 \mathrm{mg} . \mathrm{kg}$ and $5000 \mathrm{mg} / \mathrm{kg}$ body weight and it is usually carried out to determine whether or not a substance is safe for human use, in this investigation different biochemical parameters were analysed from the serum of the albino rats such as alkaline phosphate (ALP), alanine transaminase (ALT), aspartate transaminase (AST), total bilirubin, direct bilirubin, urea, creatinine, sodium, potassium and chlorine to evaluate the liver and kidney functions.

In this research there was significant elevation $(p<0.05)$ in the alkaline phosphate (ALP) and alanine transaminase (ALT) levels among the rats treated with the extract as compared with the control group, the increase in ALP level may be due to increased functional activity of the liver and this finding is consistent with the previous report of John et al.,( 2014) which 
BAJOPAS Volume 14 Number 1,June, 2021

shows that lowered level of ALP are less ALP has been the marker enzyme for plasma membrane and is required in certain amount for proper functioning of organs. Alkaline phosphate (ALP) is a hydrolase responsible for removing phosphate groups from many types of molecules, including nucleotides, proteins and alkaloids. High ALP levels can occur if bile ducts are obstructed. ALP level increases if there is active bone formation occurring.

Alanine transaminase (ALT) is a transaminase, formerly called serum glutamate-pyruvate transaminase (SGPT). ALT is the most common in liver but may also be found in the blood. Significantly elevated level of ALT often suggest the existence of other medical problems such as liver damage, viral hepatitis, diabetes, heart failure, bile duct problems, infectious mononucleosis or myopathy. The increase in the ALT level in this work may be due to the liver damage. And this may be in of line with the findings Hydar et al., (2013) which shows that liver damage and its recovery are usually assessed by measuring the level of serum enzymes-transaminases, particularly (ALT). Alanine transaminase is a more specific indicator of liver inflammation than the aspartate transaminase. All other biochemical parameters analysed there was no significant difference between the treated groups and the control.

In toxicology, the median lethal dose $L_{50}$ is a standard measurement of acute toxicity that is

\section{REFERENCES}

Abdelrahim, S.I., Almagboul A.Z., Omar, M.E. and Elegami, Aacut. (2002). Antimicrobial activity of Psidium guajava L. Journal of Medicinal PlantFitoterapia, 73 (7-8): 713-715.

Aboudoulatif, K., Kwashie, E.G., Amegnona, A. K. A., Edmond, E. C. and Messanyi, G. (2010). Acute and sub chronic (28 days) oral toxicity studies of Hydroalcohol leaf extract of Agaratum conyzoides, L (Asteroceae). Journal of Pharmaceutical Research 9(5):463-467

El-Mahmood, A.M., Ogbonna, O. B. and Raji, M. (2010). The antibacterial activity of Azadarichta indica (neem) seeds extracts against bacterial pathogens asso ciated with eye and ear infections. Journal of Medicinal Plants Research;4(14): 1414-1421

Garode, A. M. and Waghode, S. M. (2014). Antibacterial activity of Psidium guajava Linn(Guava) leaves extract on bacterial pathogens. International Journal of Bioassays; 3 (02):1794-1796. common than elevated levels. in milligrams $(\mathrm{mg})$ of toxin per kilogram $(\mathrm{kg})$ body weight. Thus, the value of $L_{50}$ for substance is the dose required to kill half the members of a tested population after specific test duration. The result obtained in the present study showed that there was no mortality at the dose limit of 2000 and $5000 \mathrm{mg} / \mathrm{kgbw}$ following oral administration with methanolic leaf extract of $P$. guajava and there was no any sign of toxicity in all the treated rats. This suggest that the methanolic leaf extract of $P$. guajava is therefore relatively harmless acutely.

\section{CONCLUSION}

This research revealed that the crude leaves extract of Anogeissus leiocarpus and Psidium guajava possess antibacterial activity against the test isolates. Anogeissus leiocarpus was active only against Staphylococcus aureus, with an inhibition zone that ranges from $7 \mathrm{~mm}$ to $15 \mathrm{~mm}$, whereas Psidium guajava was active against both $S$. aureus and $E$. coli producing higher zones of inhibition of 19 and $9 \mathrm{~mm}$ respectively.. The study demonstrated that Psidium guajava had no toxic effects based on the physical, behavioural and biochemical (liver and kidney function) parameters assessed as such the plants is suitable for human consumption. As such, the study identified Psidium guajava as the best and safe plant with promising antibacterial activity.

Hugo, W. B.and Russell, A. D. (1992). Pharmaceutical Microbiology. $5^{\text {th }}$ ed. Blackwell Scientific Publication, Oxford London, 258-297.

Hydar, M. A., Hassan, M. and Moheildein, A. H. (2013). Comparative Level of ALT, AST, ALP and GGT in Liver associated diseases. Europian Journal of Experimental Biology, 3 (2): 280-284.

Jajari, P., Khoohaswan, P., Wongkrajang, Y., Peungvicha, P., Suriyawong, P., Saraya, $M$. L., and Ruangsomboon, $O$. (1999).Anticough and antimicrobial activities of Psidium guajava Linn. Leaf extract. J. Ethanopharmacol, 67(2):203212.

John, N. A., Shobana, G. and Keerthana, k. (2014). Protective effect of Corender sativum $\mathrm{L}$ on cadmium induced toxicity in albino rats. World Journal of Pharmacy and Pharmaceutical Sciences, 3 (8): 525-534

Klaus, J. H., Dethardt, G.,Vanessa, M., Dossahoua, T. and Stefan, P. (2004). Size-class distribution of Anogeissus leiocarpus (combretaceae) long forest- 
BAJOPAS Volume 14 Number 1,June, 2021

Savannah acetones in north Ivory coast. Journal of Tropical Ecology, 21, 273-281

Koneman, E. W., Staphen, D. A., Willian, M. J., Paul, C. S., and Washington C.W. (2005) Color Atlas and Textbook of Diagnostic Microbiology $6^{\text {th }}$ Edi Pub. J.B Lippincott Company Philadelphia pp 200-250.

National Institute for Pharmaceutical Research Development, NIPRD. (2004). Extraction of medicinal plants. Idu, Abuja, Nigeria

Oyeleke, S. B. and Manga B. S. (2008). Essentials of Laboratory Practical in Microbiology Ist' ed.Tso best Pub. Nig. 93-100.

Parekh, J. and Chanda, S. (2007). Antibacterial and phytochemical studies on twelve species of Indian medicinal plants. African Journal of Biomedical Research, 10: $175-181$.

Procedure catelogue for agappe. (2013). Agappe Diagnostic Limited 2: 04-240

Rabe, T., and Van Staden, J. (1997). Antibacterial activity of South African plants used for medicinal purposes. $J$. Ethanopharmacol, 56(1):81-87.

World Health Organisation (WHO) (2008): Training Manual: Good Laboratory Practice. Retrieved on $3^{\text {rd }}$ August, 2017 from World Health Organisation website: http://www.who.int/tdr/publications/doc uments/glp-trainer.pdf. 